\title{
e-Learning quality assessment in higher education: A mapping study
}

\author{
Alberto Ortiz-López ${ }^{\dagger}$ \\ University of Salamanca, Salamanca, \\ Spain \\ alberortiz@usal.es
}

\author{
Susana Olmos-Migueláñez \\ GRIAL Research Group, Educational \\ Research Institute, University of \\ Salamanca \\ solmos@usal.es
}

\author{
José Carlos Sánchez-Prieto \\ GRIAL Research Group, Educational \\ Research Institute, University of \\ Salamanca \\ josecarlos.sp@usal.es
}

\begin{abstract}
Quality assessment is today a success factor and a guarantee in the implementation and development of countless initiatives, programs and strategies in a very wide variety of fields. For this reason, in an educational field in a constant transformation, the evaluation of the quality of each process, phase and tool must be understood as an essential and basic part in teaching, betting on the implementation of quality evaluation processes in the virtual environment and also trying to adapt reality to new learning environments. In the present moment, in a society in which everything has to be evaluated, the establishment of evaluation standards for new instruments and the standardization of accepted and validated processes will also make virtual teaching-learning environments more reliable and effective.

This research proposes a mapping study with the aim to find out the situation in which the research on quality evaluation in e-Learning in higher education finds itself. The criteria used for the selection of publications are concise and the complete process carried out is reflected in each of its phases. The results allow us to describe the current reality in a temporal perspective and the state of the art, in order to address the potential future lines of research in the field of quality assessment in virtual environments.
\end{abstract}

\section{CCS CONCEPTS}

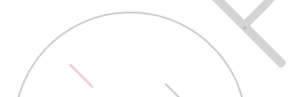

- Human-centered computing; • Human computer interaction (HCI); • HCI design and evaluation methods.

\section{KEYWORDS}

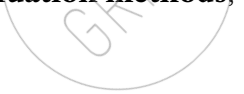

e-Learning, quality, assessment, higher education, mapping study

\section{ACM Reference Format:}

Alberto Ortiz-López, Susana Olmos-Migueláñez, and José Carlos SánchezPrieto. 2020. e-Learning quality assessment in higher education: A mapping study. In Eighth International Conference on Technological Ecosystems for Enhancing Multiculturality (TEEM'20), October 21-23, 2020, Salamanca, Spain. ACM, New York, NY, USA, 6 pages. https://doi.org/10.1145/3434780.3436602

\section{INTRODUCTION}

Quality and quality assessment are acquiring an important increase in their social interest in recent years, in which everything has to be evaluated and in which quality seals and labels have become a clear objective for any organization, institution or project.

Accordingly, quality has become a crucial objective for most of our universities, both at the political, institutional and individual level. The achievement of quality implies an adequate planning of the processes of evaluation and an improvement of the operation of the institution as a whole in matters of teaching, research, management, administration and provision of the services offered [1].

To talk about the educational world is, inexorably, to talk about an area in constant transformation and development, a process directed in the last decades towards the digitization and network implementation of the traditional education.

In this context appears the term eLearning, defined by GarcíaPeñalvo [2] from an educational perspective as:

a non-face-to-face training that, through technological platforms, enables and makes access and time more flexible in the teaching-learning process, adapting them to the skills, needs and availability of each student, in addition to guaranteeing collaborative learning environments through the use of synchronous and asynchronous communication tools, thus enhancing the competency-based management process (p. 2).

The concept of online teaching (e-Learning) is a term in evolution and adaptation to the new technological frameworks that varies the place and presence of this methodology [3].

This process has caused the arousal of different modalities of eLearning. This way, from the face-to-face point of view, we can find: Direct e-Learning (face-to-face), Blended Learning (combination of face-to-face sessions with online training) and Online Learning (completely online training). On the other hand, from the point of view of the supports used we can find e-Learning (electronic), mLearning (with mobile devices) and u-Learning, a modality in which learning can occur at any time and place and is also independent of the devices.

The implementation of e-Learning models at present produces changes in teaching-learning process that can be grouped as [4]:

- Changes in teacher profile: New skills since he is no longer the only transmitter of content.

- Changes in the student profile: The student is now the center of the process, responsibility in a more collaborative job. 
- Appearance of new professional profiles (pedagogical, technical and institutional) for the management of online training.

These implications highlight the key importance of ensuring the quality achieved during the implementation of eLearning, which can be defined as

the adequacy and direct relationship of technical, human, technological resources, methods and tools used in the virtual teaching-learning process, according to the needs and expectations of students and society in order to guarantee the optimization of the learning process. learning in the effective practice of the knowledge and skills acquired in this modality [5].

Since the 1990s, higher education institutions have begun to direct their processes and teachings towards virtual environments, making a firm commitment with their quality.

This transition has been supported by countless political strategies both at national and international level, such as the Lisbon Strategy (Special Session of the Lisbon European Council) in 2000. This strategy advocated transforming the European economy into a global power, being a fundamental pillar the quality of education and the realization of a strong commitment to e-Learning [6].

However, to guarantee quality, it is essential to use a model of evaluation that goes beyond the socially extended and recognized (evaluation as a summative process or final qualification of it), and that is conceived as a fair, objective and demanding tool to be able to assign the qualifier of quality to any process.

To analyze this object and to deepen in the knowledge of the advantages of e-Learning and the feasibility of its implementation in higher education, in 2008 the Swedish National Agency for Higher Education carried out a study that sought to know the components of quality in virtual environments and how it can be achieved. The resulting model was called the ELQ model, the result of work on the practices carried out at the educational level in e-learning in Europe, which includes aspects and criteria to assess, the quality of e-Learning in higher education [7].

Subsequently, the accreditation and quality certification models in e-Learning have been specialized and disseminated, finding models such as UK IT TRAINING (ITTT), E-LEARNERS CHARTERS, ODL QC STANDARS, CERTIFICATION E-LEARNING PROFESSIONAL (CeLP), BAOL QUALITY MARK; among others [8].

As we can see, there are innumerable models available to evaluate the quality of e-Learning, which highlights the importance and relevance that the advances in the field of virtual education have had in recent years.

However, to the best of our knowledge, there is a lack of recent studies that offer a systematic review of the state of the art on this topic. This research aims to contribute to filling the research gat through a mapping study focused on knowing the number of studies carried out on the assessment of quality in e-Learning in higher education institutions, the place of realization of them, their annual evolution, the authors who lead the subject and the methodology used.

In order to present the research, the remainder of the paper is structured as follows. Section two presents the methodology employed for the mapping study including the research questions,
Table 1: Mapping questions

\begin{tabular}{ll}
\hline Question & Description \\
\hline MP1 & How has the number of publications evolved? \\
MP2 & Which authors are the most relevant? \\
MP3 & In which journals are the publications found? \\
MP4 & In which countries have the studies been carried \\
& out? \\
MP5 & What types of research are the most carried out? \\
\hline
\end{tabular}

the inclusion/exclusion criteria, the search string, and the selection process. Section three includes the results obtained after the analysis of the papers selected answering the questions stablished. Finally, section four explores the implications of the results, the limitations of the study and the future lines of research derived from the investigation.

\section{METHODOLOGY}

This investigation carries out a mapping study, a technique that facilitates the comprehensive review of primary studies in a given area, which aims to identify the main evidence available on the subject under study from a global and objective perspective [9].

In this research we will follow the structure stablished by Kitchenham and Charters, whom summarize and group the moments of an SLR into three major phases, which are: Approach to the review (identification of needs, questioning, inclusion and exclusion criteria , approach to a protocol), review (selection of the publications found in the databases, extraction of the information and monitoring of data) and reporting the results. This section summarizes both, the design of the mapping study (phase 1), and the results of the selection process.

\subsection{Research questions}

The first step in the development of a mapping study is the formulation of the questions intended to be answered. This research questions must be clear, concise and relevant in order to facilitate the analysis of the results and the presentation of the same. The following research questions were formulated for this mapping study (Table 1).

\subsection{Inclusion and exclusion criteria}

Mapping studies and systematic reviews require a series of explicit, clear and objective inclusion and exclusion criteria to evaluate each primary study. These criteria are useful to determine which articles meet the established requirements and which must be discarded, and they are a fundamental part for the correct development of the systematic review [10].

\subsubsection{Inclusion Criteria.}

I1 The articles deal with the assessment of the quality of eLearning in higher education, understanding as such the definitions that are presented at the end of these criteria.

I2 Publications must be articles that have undergone a peer review process.

I3 Articles have been published in the last five years. 
I4 The articles are written in Spanish or English.

I5 The articles deal with e-Learning in its entirety, not exclusively with any of its modalities (blended-Learning, mobileLearning, u-Learning ...).

I6 The articles present empirical studies.

\subsubsection{Exclusion Criteria.}

E1 The articles that do not deal with e-Learning quality assessment in higher education.

E2 The publications are not scientific articles submitted to a peer review process.

E3 The articles have been published before the last five years.

E4 The articles are written in languages other than Spanish or English have been excluded.

E5 Articles that are not empirical studies or include a content validation process by expert judges.

E6 Articles that do not deal with e-Learning in its entirety (blended-Learning, mobile-Learning, etc.).

Given the diversity of definitions of eLearning and in order to clarify the criteria, we took as a reference the definition of GarcíaPeñalvo previously mentioned in the introduction. Therefore, any article that refers to e-Learning as partially face-to-face or nonface-to-face teaching, flexible and that uses both synchronous and asynchronous communication tools, will be valid.

However, in order to make this investigation a serious restriction on the state of the art in higher education (exclusively), MOOCs and open education courses have not been included in this review, since it cannot be guaranteed that they have people exclusively linked to the field of higher education as creators or participants.

Finally, we considered valid any article that conceives eLearning quality as the degree to which an eLearning course, program or teaching meets established requirements and that implies a correct and in-depth planning, evaluation and improvement in the teaching and research processes and in the areas of management and administration. Likewise, quality must also guarantee the optimization and maximization of the teaching-learning process in terms of the knowledge and skills acquired by the participants and the way in which these are transmitted.

\subsection{Search string and databases}

The search was carried out on 26/11/2019 in the Web of Science and Scopus databases, the most relevant in the research field [11]

The search string used was:

("Quality Evaluation" OR "Quality Assessment") AND ("eLearning" OR "e-Learning") AND ("Higher Education" OR "University" OR "Higher Education" OR "University")

The database with the articles, the complete process and the reviews carried out is available for free access at the link: https://docs.google.com/spreadsheets/d/1Ll3dPdTycPkZhmHwQn9aE4PRPSJ3-vgXy7A3Mco7ow/edit?usp=sharing

The initial search yielded 639 articles that where included in the first phase of the Investigation. After removing duplicates, the number dropped to 630 papers.

In the second phase of the research, the exclusion criteria already referred to in this work were applied. The result after the first application of criteria was 28 articles accepted and 19 proposed for later review (47 articles).

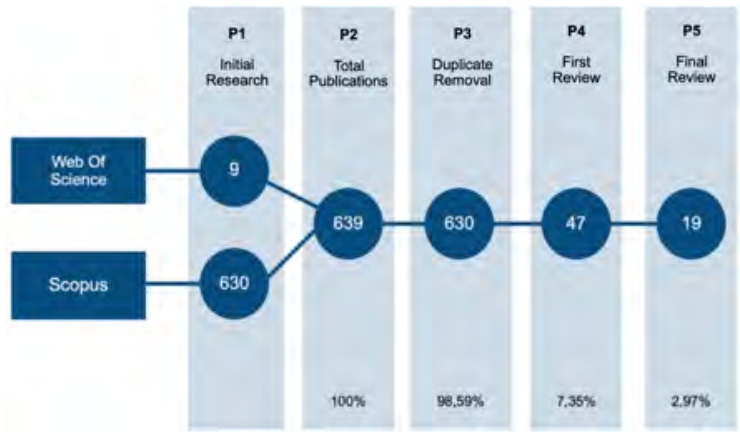

Figure 1: Article selection process

After this, the review and discussion of the articles marked for this process and those already accepted was also requested with a professor and researcher who is an expert in the field and in the development of mapping / SLR-type studies.

It was in this phase of the investigation that the final object of the investigation was more specific; rejecting MOOC-type studies and open education (due to their nature, as has already been stated during the development of this work) and those publications that exclusively referred to e-Learning in a single of its modalities were also discarded (mobile -Learning, blended-Learning); Since this research seeks to know how is the assessment of quality in the globality of e-Learning, without focusing on a single part due to the impossibility of extrapolation of it to the whole.

Likewise, the decision was also made to include those articles that referred to different phases of the e-Learning process, since it provides a more precise vision of those phases that are most studied in relation to the assessment of its quality and those that allow the opening of new avenues of investigation.

Finally, with the clear objective of guaranteeing the validity, objectivity and improving the reliability of the research, we requested a review by two expert judges of fifty random articles to verify the validity of the application of the criteria carried out to date. The judges determined that $100 \%$ of the excluded / included articles that were reviewed were correctly ruled, which allowed this research to continue with a higher degree of validity.

In relation to the number of publications promoted in each phase, the final number of accepted publications was 19 (with an acceptance percentage of $2.97 \%$ ) and a total of 620 rejected articles (Figure $1)$.

\section{RESULTS}

The first question posed in the mapping (MP1) refers to the evolution of the number of publications during the last five years. To this end, the year of publication of each accepted research has been taken into account (Figure 2).

In the evolution of the publications can be seen how the number of them increases in the last year, going from a downward trend since 2016, to a total of six publications in 2019. This trend may be justifiable in the digital transition that higher education institutions are making and in the importance that they are giving to the assessment of its quality. 


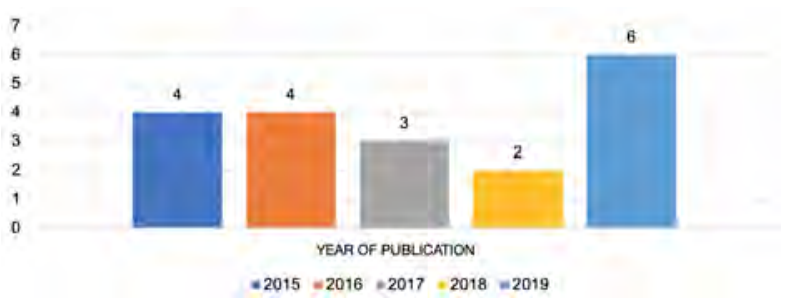

Figure 2: Number of articles depending on the year of publication

Table 2: Authors based on the number of publications

\begin{tabular}{ll}
\hline $\begin{array}{l}\text { Number of } \\
\text { Publications }\end{array}$ & Author \\
\hline 2 & Kaur, K.; Marciniak, R.; Waheed, M. \\
1 & Arroyo, G.C.; Barcia-Tirado, D.M.; \\
& Batalla-Busquets, J.-M.; Bui, T.K.; Ceballos, S.P.; \\
& Cegarra-Navarro, J.G.; Cepeda-Carrioń, G.; \\
& Choi, C.-R.; Cisneros-Cohernour, E.; Clavijo, V.; \\
& De-Pablos-Heredero, C.; Ducange, P.; \\
& Farasatkhah, M.; Garciá, P.A.; Gonzalez, M.S.; \\
& Gore, J.; Holmes, K.; Jankulovic, A.; Jeong, H.-Y.; \\
& Kurilovas, E.; La Rotta, D.; Lim, K.; Limbu, Y.B.; \\
& Mahdiuon, R.; Margalina, V.M.; Martin Nunẽz, \\
& J.L.; Martińez-Arguëlles, M.-J.; Martińez-Caro, \\
& E.; Masoumi, D.; Montes- Botella, J.L.; Nguyen, \\
& H.T.; Ortiz, P.; Park, Y.; Pecori, R.; Pham, H.T.; \\
& Pham, L.; Prieto-Rodriguez, E.; Qazi, A.; \\
& Raspopovic, M.; Serrano, E.L.; Suraci, V.; \\
& Torres-Barzabal, L.M.; Usuga, O.C.; \\
& Vinogradova, I. \\
&
\end{tabular}

The second question (MP2) refers to the most relevant authors in the analyzed publications (Table 2). After the analysis, it cannot be concluded that there is one or more authors who stand out notably above the rest in terms of their number of publications, since it is only Kiran Kaur, Renata Marciniak and Mehwish Waheed who have two publications, while the rest of the authors only have one publication.

The third mapping question (MP3) is related with the sources of publication of the articles (Table 3). The articles included in this study have been published in 24 different scientific journals, of which two of them (International Review of Research in Open and Distance Learning and Turkish Online Journal of Distance Education) have two publications while the rest only present one.

The fourth question (MP4) aims to find out which countries have the greater number of publications in order to identify the geographic areas more interested in the assessment of the quality in e-Learning.

The results (Figure 3) show that Spain is the country with the most published research on the subject of study, since seven articles (36.85\% of the total) have been written here. South Korea and
Table 3: Journals based on the number of publications

\begin{tabular}{ll}
\hline $\begin{array}{l}\text { Number of } \\
\text { Publications }\end{array}$ & Journal \\
\hline 2 & $\begin{array}{l}\text { International Review of Research in Open and } \\
\text { Distance Learning, Turkish Online Journal of } \\
\text { Distance Education }\end{array}$ \\
& $\begin{array}{l}\text { International Journal of Engineering Education, } \\
\text { Internet Research, Learning Environments }\end{array}$ \\
& $\begin{array}{l}\text { Research, Multimedia Tools and Applications, } \\
\text { Opcion, Revista Electronica de Investigacioń }\end{array}$ \\
& Educativa, Revista Iberoamericana de \\
& Tecnologiás del Aprendizaje, RUSC Universities \\
& and Knowledge Society Journal, Studies in \\
& Higher Education, TechTrends, Total Quality \\
& Management and Business Excellence
\end{tabular}

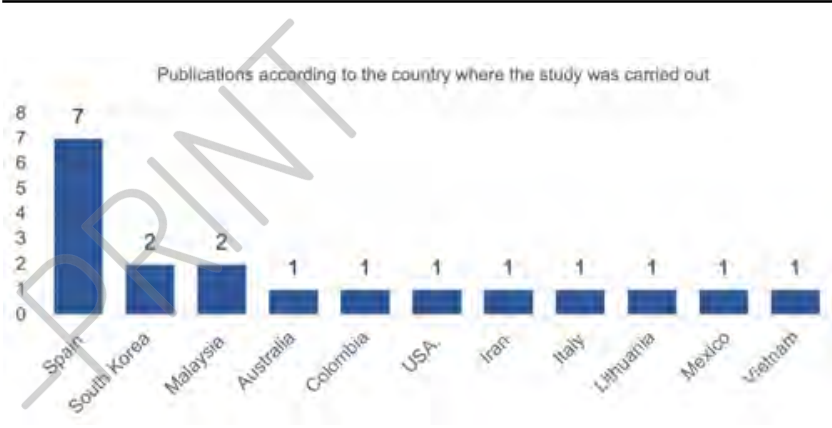

Figure 3: Publications according to the country where the studies were carried out

Number of studies depending on the type of research carried out

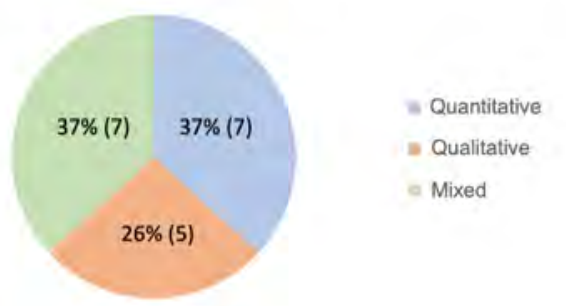

Figure 4: Number of studies depending on the type of research carried out

Malaysia are far behind Spain with two publications each, and the rest of the countries have only one publication.

Finally, question five (MP5) asks to know what type of research methodology has been carried out, distinguishing between qualitative research, quantitative research and mixed research (Figure 4). The results show that the majority of the studies are quantitative ([12-18]) and mixed ([19-25]), with seven studies each one; and only five are qualitative ([26-30]). 


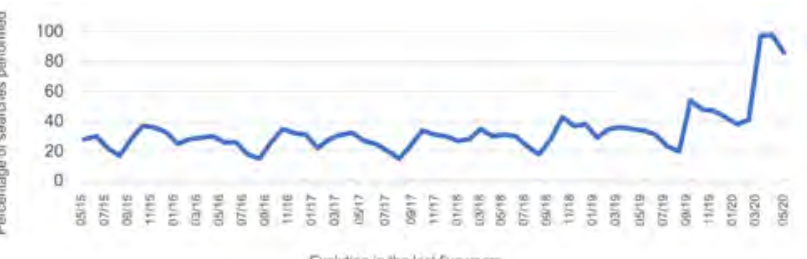

Figure 5: Internet searches for "e-Learning" term.

\section{DISCUSSION}

In the analysis of the results obtained after carrying out the mapping, we can observe an increase in the number of studies performed in recent years, which shows a growing interest in the scientific and educational community in the research of the quality assessment processes in this teaching modality.

Even so, and despite this trend, there are still very few authors and resources focused on evaluating quality in virtual environments, so a greater effort and involvement is required to position the quality factor as relevant in virtual environments, and defend the same as a key factor for the success and development of a program, teaching or institution.

As for the country of origin of the publications, it is detected that Spain is at the forefront in terms of publications on quality assessment in e-Learning in higher education, which may be due to the fact that the search carried out for the mapping contains the terms both in English and Spanish (as can be seen in the search string).

With the transition to remote teaching that COVID-19 has meant; there have been countless research groups, Universities and entities (public and private) that have implemented measures aimed at training teachers and students in online teaching and evaluation processes. A sample that reflects the exponential interest that nonface-to-face teaching takes at the present time and its evaluation is reflected in the announcements made by multiple scientific journals that, due to the pandemic and the educational changes that are taking place, have announced the publicafion of special and monographic issues on e-Learning and all the phases and components that this type of learning involves. Some of these journals are: Journal of Lifelong Learning, IAFOR, European Educational Research Journal, Educational Studies in Mathematics, International Journal of Educational Research and Innovation, Scholarship of Teaching and Learning in Psychology... .

Another clear example that reflects this interest is the list of searches on the net for the "e-Learning" term (Figure 5), which shows an increase in the implementation of online assessment processes and the underlying need to evaluate the quality of these training processes.

These changes in teaching modalities and the continuous advances towards areas where presence loses prominence and technology becomes a fundamental means, make e-Learning become a protagonist in our educational systems.

The mapping carried out in this research has allowed us to know the situation regarding the e-Learning quality assessment in higher education at the present time, providing a global and objective vision in the absence of studies of this type.
After knowing the general panorama of the studies carried out in the last five years, this mapping presents a snapshot of the investigations carried out so far prior to the start of the COVID-19 crisis, therefore, this mapping can also guide future studies that may be carried out in this area, in the transformation of e-Learning and in the improvement of quality processes.

The main limitation that this research has found is the constant transformation in the digital field, which makes us face a difficult field to narrow down. In addition, the lack of common protocols for the assessment of quality in e-Learning also means that some lines followed are confusing in their interpretation and in the delimitation of it, depending mainly on the institution of higher education that carries it out.

This mapping, which is part of a broader and in-depth study on the assessment of quality in e-Learning in higher education, also opens up new lines of future research, among which includes the deepening of new mapping questions (use of instruments or scales, who is in charge of this evaluation process...) and the approach of an SLR study to know how these processes are in depth.

\section{ACKNOWLEDGMENTS}

This work has been partially funded by the Spanish Government Ministry of Economy and Competitiveness through the DEFINES project (Ref. TIN2016-80172-R).

\section{REFERENCES}

[1] Baltasar Fernández, Enrique Alonso, Enrique Rebolloso, and Carmen Pozo. 1999. Evaluación de la calidad en la educación superior. Papeles del psicólogo 74 (Nov, 1999), 1886-1415.

[2] Francisco J. García-Peñalvo. 2005. Estado actual de los sistemas e-Learning. Teoría de la Educación. Educación y Cultura en la Sociedad de la Información 6, 2 (2005). Retrieved from https://www.redalyc.org/articulo.oa?id=2010/201021055001

[3] Rafael Ramiro. 2019. Universidad en España: cómo avanza nuestra transformación digital. Rafael Ramiro. Retrieved November 23, 2019 from https://rafaelramiro. com/universidad-en-espana-como-avanza-nuestra-transformacion-digital/

[4] Ana Viñals and Jaime Cuenca. 2016. El rol del docente en la era digital. Revista Interuniversitaria de Formación del Profesorado 30, 2 (Aug, 2016), 103-114.

[5] Antonio M. Seoane and Francisco J. José García-Peñalvo. 2010. Introducción al eLearning. GRIAL. Grupo de Investigación en InterAcción y eLearning.

[6] José F. Mejía and Diego López. 2016. Modelo de Calidad de E-learning para Instituciones de Educación Superior en Colombia. Formación Universitaria 9, 2 (2016), 59-72. DOI: http://dx.doi.org/10.4067/S0718-50062016000200007

[7] Alberto Mixnahuatl, Jessica Santamaría, Argelia Urbina, Jorge de la Calleja, and María Auxilio. 2013. Diseño del curso análisis de sistemas aplicando el modelo de calidad para e-learning. In Educación Handbook T-I: Congreso Interdisciplinario de Cuerpos Académicos, Ecorfan, México, 143-152.

[8] Viviana Fernández. 2005. Calidad y e-learning. En F.F. Martínez (Coord). In E-aprendizaje en bibliotecología: perspectivas globales. Universidad Nacional Autónoma de México, México, 74-91.

[9] Barbara Kitchenham and Stuart Charters. 2007. Guidelines for performing Systematic Literature Reviews in Software Engineering. Keele University and Durhan University, Alemania.

[10] Francisco J. García-Peñalvo. 2017. Revisión sistemática de literatura en los Trabajos de Final de Máster y en las Tesis Doctorales. Retrieved January 12, 2020 from https://knowledgesociety.usal.es/sites/default/files/20170316\%20\%20Seminario\%20SLR.pdf

[11] Ana Pérez-Escoda. 2017. WoS y Scopus: los grandes aliados de todo investigador. Comunicar (2017). DOI:https://doi.org/10.3916/escuela-de-autores-031

[12] Pedro A. García and María S. González. 2015. Validación de escala para evaluación de la calidad docente en entornos virtuales. Opción: Revista de Ciencias Humanas $y$ Sociales 31, 5 (2015), 394-406.

[13] Eugenijus Kurilovas and Irina Vinogradova. 2016. Improved fuzzy AHP methodology for evaluating quality of distance learning courses. The International journal of engineering education 32, 4 (2016), 1618-1624.

[14] Vasilica Margalina, Carmen De Pablos-Heredero, and José Luis Montes. 2015. Achieving quality in e-Learning through relational coordination. Studies in Higher Education 42, 9 (2015), 1655-1670. 
[15] Eva Martínez-Caro, Juan G. Cegarra-Navarro, and Gabriel Cepeda-Carrión. 2015 An application of the performance-evaluation model for e-learning quality in higher education. Total Quality Management \& Business Excellence 26, 5-6 (2015), 632-647.

[16] Riccardo Pecori, Vincenzo Suraci, and Pietro Ducange. 2019. Efficient computation of key performance indicators in a distance learning university. Information Discovery and Delivery 47, 2 (2019), 96-105.

[17] Long Pham, Yam B. Limbu, Trung K. Bui, Hien T. Nguyen, and Huong T. Pham 2019. Does e-learning service quality influence e-learning student satisfaction and loyalty? Evidence from Vietnam. International fournal of Educational Technology in Higher Education 16, 7 (March 2019), 1-26.

[18] Miroslava Raspopovic and Aleksandar Jankulovic. 2017. Performance measurement of e-learning using student satisfaction analysis. Information Systems Frontiers 19, 4 (2017), 869-880.

[19] Cheol-Rim Choi and Hwa-Young Jeong. 2019. Quality evaluation for multimedia contents of e-learning systems using the ANP approach on high speed network. Multimedia Tools and Applications 78, 4 (2019), 28853-28875.

[20] Daniel La Rotta, Olga Cecilia Usuga, and Valentina Clavijo. 2019. Perceived service quality factors in online higher education. Learning Enviroments Research 23, (2019), 251-267.

[21] Renata Marciniak. 2018. Quality Assurance for Online Higher Education Programmes: Design and Validation of an Integrative Assessment Model Applicable to Spanish Universities. The International Review of Research in Open and Distributed Learning 19, 2 (2018), 126-154.
[22] María Martínez-Argüelles and Josep-Maria Batalla-Busquets. 2016. Perceived Service Quality and Student Loyalty in an Online University. The International Review of Research in Open and Distributed Learning 17, 4 (July 2016), 264-276.

23] Youngran Park and Keol Lim. 2015. Effects of Environmental and Human Constructs on E-learning Effectiveness in Online University Settings. Indian fournal of Science and Technology 8, 1 (February 2015), 103-109.

[24] Elena Prieto-Rodríguez, Jennifer Gore, and Kathryn Holmes. 2016. Exploring Quality Teaching in the Online Environment Using an Evidence-Based Approach. Australian fournal of Teacher Education 41, 8 (2016), 22-39.

[25] Mehwish Waheed, Kiran Kaur, and Atika Qazi. 2016. Students' Perspective on Knowledge Quality in eLearning Context: A Qualitative Assessment. Internet Research 26, 1 (2016), 120-145.

[26] Rouhollah Mahdiuon, Davoud Masoumi, and Maghsoud Farasatkhah. 2017. Quality improvement in virtual higher education: A grounded theory approach. Turkish Online Fournal of Distance Education 18, 1 (2017), 111-131.

[27] Renata Marciniak. 2015. Methodological proposal for the application of international benchmarking in order to assess the quality of virtual higher education. RUSC. Universities and Knowledge Society fournal 12, 3 (2015), 46-60.

[28] Edna L. Serrano, Salvador P. Ceballos, Graciela Cordero, and Edith CisnerosCohernour. 2018. Marco para evaluar las condiciones institucionales de la enseñanza en línea. Revista Electrónica de Investigación Educativa 20, 2 (May 2018), $1-14$

[29] Luisa Torres Barzabal, Pilar Ortiz, and Dolores Barcia-Tirado. 2018. Quality Indicators for Auditing on-Line Teaching in European Universities. TechTrends 63, 3 (2018), 330-340

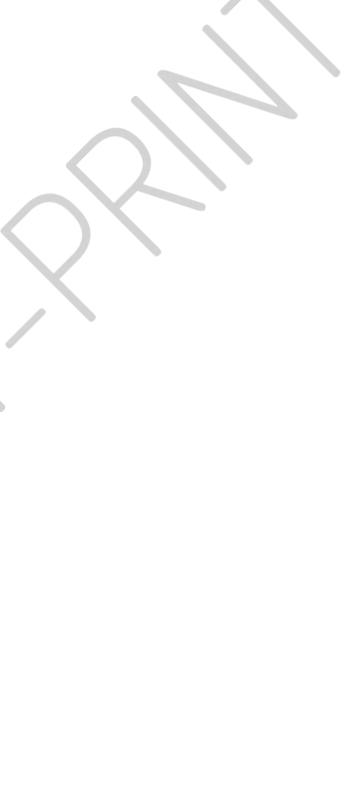

